\title{
Brazilian version of the Sociocultural Attitudes towards Appearance Questionnaire (SATAQ-3) for adolescents
}

\author{
Gabriela Salim Xavier Moreira. Universidade de São Paulo, Ribeirão Preto \\ Luciana Lorenzato. Universidade de São Paulo, Ribeirão Preto \\ Carmem Beatriz Neulfeld. Universidade de São Paulo, Ribeirão Preto \\ Sebastião Sousa Almeida. Universidade de São Paulo, Ribeirão Preto
}

\begin{abstract}
The study adapted the Questionnaire of Sociocultural Attitudes Regarding Appearance (SATAQ-3) for Brazilian adolescents. We tested the factorial structure using confirmatory factorial analysis (CFA), exploratory factorial analysis (EFA), concurrent validity and internal consistency in 347 adolescents (171 males) aged 10-13 years. The AFC did not find a good fit of our sample to the models. The AFE, however, resulted in satisfactory adjustment, with factorial structure of six factors explaining slightly more than $50 \%$ of the variance. Correlations between SATAQ-3 scores and body image estimation and satisfaction indices, as well as the Body Mass Index, showed concurrent validity of the instrument. The internal consistency is adequate for the general sample and for groups stratified by sex ( $a$ Cronbach> 0.804). It has been shown that SATAQ-3 is suitable for administration to Brazilian adolescents aged 10-13 years to analyze sociocultural pressures and the internalization of appearance ideals.
\end{abstract}

Keywords: body image, adolescents, Brazilian population, psychometric properties, SATAQ-3.

\section{Resumo}

Versão brasileira do Questionário de Atitudes Socioculturais em Relação à Aparência (SATAQ-3) para adolescentes. O estudo adaptou o Questionário de Atitudes Socioculturais em Relação à Aparência (SATAQ-3) para adolescentes brasileiros. Testamos a estrutura fatorial utilizando análise fatorial confirmatória (AFC), análise fatorial exploratória (AFE), validade concorrente e consistência interna em 347 adolescentes (171 masculinos) com 10-13 anos. A AFC não encontrou um bom ajuste da nossa amostra aos modelos. A AFE, no entanto, resultou em ajuste satisfatório, com estrutura fatorial de seis fatores explicando ligeiramente mais de $50 \%$ da variância. Correlações entre os escores do SATAQ-3 e os índices de estimação e satisfação com a imagem corporal, além do Índice de Massa Corporal, mostraram validade concorrente do instrumento. A consistência interna é adequada para a amostra geral e para grupos estratificados por sexo (a Cronbach > 0,804). Demonstrou-se que o SATAQ-3 é adequado para a administração a adolescentes brasileiros de 10-13 anos para analisar as pressões socioculturais e a internalização dos ideais de aparência.

Palavras-chave: imagem corporal, adolescentes, população brasileira, propriedades psicométricas, SATAQ-3.

\section{Resumen}

Versión brasileña del Cuestionario sobre Actitudes Socioculturales Hacia la Apariencia (SATAQ-3) para adolescentes. El estudio adaptó el Questionario de Actitudes Socioculturales con Respecto a la Apariencia (SATAQ-3) para adolescentes brasileños. Probamos la estructura factorial mediante análisis factorial confirmatorio (CFA), análisis factorial exploratorio (EFA), validez concurrente y consistencia interna en 347 adolescentes (171 hombres) de 10-13 años. La AFC no encontró buen ajuste de nuestra muestra a los modelos. Sin embargo, la AFE resultó en ajuste satisfactorio, con estructura factorial de seis factores explicando poco más del 50\% de la varianza. Correlaciones entre los puntajes SATAQ-3 y los índices de estimación y satisfacción de la imagen corporal, así como el Índice de masa corporal, mostraron validez concurrente del instrumento. La consistencia interna es adecuada para la muestra general y para los grupos estratificados por sexo ( $a$ Cronbach> 0.804 ). Se ha demostrado que SATAQ-3 es adecuado para administración a adolescentes brasileños de 10-13 años para analizar las presiones socioculturales y la internalización de los ideales de apariencia. Palabras clave: imagen corporal, adolescentes, población brasileña, propiedades psicométricas, SATAQ-3. 
Recent studies found that media messages and sociocultural pressures are principal risk factors for body image dissatisfaction, weight concerns, and disordered eating behavior among adolescents of both sexes (Fortes et al., 2015; Spurr, Berry, \& Walker, 2013). Hargreaves and Tiggemann (2004) found that exposure to thin-idealized commercials increased body dissatisfaction, especially in adolescent girls. Previous studies found that the immediate impact of media messages on body image was stronger and more widespread among girls than boys. One recent study, however, reported that the negative impact of social media, for example, is the same for both sexes (Vries, Peter, Graaf, \& Nikken, 2016). It confirms other studies that conclude that adolescent boys also experience body dissatisfaction as some factors that affect girls' body image also impact boys' body image (Ricciardelli \& McCabe 2004).

One of the main explanatory models of the influence of culture and society on body image is the Tripartite Model that was proposed by Thompson, Coovert and Stormer (1999). According to this model, three basic factors influence the development of body image disorders: peers, family, and media. These factors are mediated by social comparisons and the internalization of appearance ideals that emphasize thinness for women and muscularity for men. Internalization of these often-unattainable ideals is thought to lead to body dissatisfaction among adolescent girls (Fortes, Amaral, Almeida, \& Ferreira, 2013; Rodgers, Cabrol, \& Paxton, 2011). Also there is evidence that boys, especially in the first phase of adolescence, are also dissatisfied with their bodies, but they want a larger body (Fidelix, Minatto, Ribeiro, Santos, \& Petroski, 2013).

With regard to the importance of sociocultural pressures and the internalization of appearance ideals to the development of body image disturbances and eating disorders, it is necessary to accurately assess these constructs using well-validated and reliable measures. The Sociocultural Attitudes Towards Appearance Questionnaire (SATAQ; Heinberg, Thompson, \& Stormer, 1995) is one of the most widely used scales that is used to investigate these factors. The third version of the SATAQ (SATAQ-3), published by Thompson et al. (2004), consists of a 30-item scale with four dimensions. Two of these subscales are based on different internalization factors. One of the subscales is "General Internalization," which assesses the general influence of the media (e.g., TV, magazines, and movies). The other subscale is "Athletic Internalization," which assesses the internalization of athletic and sports models. The other two subscales are "Information" (which assesses the media as a source of information about appearance) and "Pressure" (which assesses subjective feelings of pressure from the media to adhere to appearance standards). Importantly, we did not use other instruments that assess similar constructs as the SATAQ-3 to study convergent validity because few scales have been cross-culturally adapted and validated for this age group. For example, the Tripartite Influence Scale measures the influence of parents, friends, and media on body dissatisfaction and eating disorders. A cross-cultural adaptation has been properly performed for Brazilian Portuguese, but its psychometric properties were evaluated only among undergraduate students.

The SATAQ-3 has been translated and validated among various samples and different populations, including women from Jordan (Madanat, Hawks, \& Brown, 2006), Britain (Markland \& Oliver, 2008), and Malaysia (Swami, 2009), American male undergraduates (Karazsia \& Crowther, 2008), adolescent samples from Germany (Knauss, Paxton, \& Alsaker, 2009), France (Rousseau, Valls, \& Chabrol, 2010), China (Jackson \& Chen, 2010), Italy (Stefanile, Matera, Nerini, \& Pisani, 2011), and Spain (Sánchez-Carracedo et al., 2012), and patients with eating disorders (Calogero, Davis, \& Thompson, 2004; Heinberg et al., 2008).

The Brazilian version of the SATAQ- 3 was developed through a cross-cultural adaptation that was performed by Amaral, Cordás, Conti and Ferreira (2011). This Brazilian version had satisfactory translational integrity among experts and Brazilian youths. Psychometric properties were tested among undergraduate students and adolescents who were $\geq 13$ years old (Amaral, Conti, Ferreira, \& Meireles, 2015; Amaral, Ribeiro, Conti, Ferreira, \& Ferreira, 2013). In the first study, exploratory factor analysis (EFA) revealed the presence of five factors: four represented the same original factors, and one was composed of the reverse-keyed items that were grouped to form an independent factor. This structure was also tested by confirmatory factor analysis (CFA), which indicated acceptable construct validity for the Brazilian population among adult samples with similar characteristics. With regard to reliability, Cronbach's a of 0.91 (0.92 for males, 0.91 for females) was obtained for the instrument's internal consistency. Test-retest reliability was also satisfactory, with an intraclass correlation coefficient of 0.87 (Amaral et al., 2013).

The second study that sought to validate the Brazilian version of the SATAQ-3 included adolescents who were $>13$ years of age. In this study, Amaral et al. (2015) also found variation in the factor structure 
compared with the original version. The authors noted a seven-factor structure: general internalization by comparison (factor 1), pressure (factor 2), information from television (factor 6), information from other media sources (factor 3), athletic internalization (factor 4), general internalization by socio-cultural standards (factor 7), and reverse-keyed questions (factor 5). The internal consistency of the SATAQ- 3 was adequate for the total sample and stratified by sex, with a Cronbach's $\alpha>0.83$.

A recent review of the Brazilian literature on body image published by Laus et al. (2014) reported advances in the field, reflected by a large increase in the number of available instruments. Only two of 44 instruments, however, assess sociocultural influences on body image: Tripartite Influence Scale and SATAQ-3. However, only the SATAQ-3 measures the influence of media internalization on body image.

Adolescence is a stage of life when the individual is more vulnerable to sociocultural influences on appearance (Wertheim \& Paxton, 2011). The media transmits body patterns through the mass media, such as television, magazines and cinema, so when adolescents are exposed to images that fit the current beauty pattern, they get the message of how they should look to be judged attractive (Watson \& Vaughn, 2006). A greater influence of the mass media was associated with a greater risk of developing eating disorders among female adolescents (Montoya, Quenaya, \& MaytaTristán, 2015). According to Rohde, Stice and Nathan Marti (2015), risk factors for eating disorders are present by early adolescence, although the diagnosis of eating disorders tends to emerge in late adolescence or early adulthood. In addition, longitudinal studies revealed that the high frequency of use of social networks predicts increased dissatisfaction with body image over time and these impacts were the same for boys and girls (Vries et al., 2016). The aim of the present study was to adapt the SATAQ-3 to the Brazilian adolescent population, age 10-13 years, and verify its psychometric properties (e.g., factor structure, internal reliability, construct validity, concurrent validity, and criterion validity).

\section{Material and methods}

\section{Participants}

The proposed study was presented to 10 private schools and two public schools in two cities of small and moderate size in the state of São Paulo. Two public schools and three private schools authorized the study with their respective students through invitations and the consent of their parents. The study included in the sample all students who were enrolled in the $5^{\text {th }}$ and $6^{\text {th }}$ grades of elementary education between 10 and 13 years of age $(M=11.10 ; S D=0.81)$.

The initial sample comprised 352 participants, but the sample was reduced to 347 (171 male and 176 female) after excluding students who presented intellectual impairment that was informed by school coordinators or presented any comprehension or language difficulties. The sample size was defined based on the recommendations of Pasquali (2010), with five to 10 participants for each item. The sample characteristics are described in Table 1. The male and female groups were statistically different for body image dissatisfaction (Diff. $=1.678 ; t^{345}=4.31 ; p<0.05$ ), wherein girls wanted to be thinner concerning boys.

Table 1. Descriptive Statistics

\begin{tabular}{|c|c|c|c|c|c|c|}
\hline & \multicolumn{3}{|c|}{ Mean (SD) } & \multicolumn{3}{|c|}{ Minimum-maximum } \\
\hline & General $(n=347)$ & Male $(n=171)$ & Female $(n=176)$ & General $(n=347)$ & Male $(n=171)$ & Female $(n=176)$ \\
\hline Age (years) & $11.10(0.81)$ & $11.13(0.80)$ & $11.06(0.81)$ & $10.00-13.00$ & $10.00-13.00$ & $10.00-13.00$ \\
\hline Weight (kg) & $46.08(12.56)$ & $45.26(12.68)$ & $46.87(12.43)$ & $24.30-90.20$ & $24.30-89.10$ & $24.50-90.20$ \\
\hline Height (m) & $1.50(0.09)$ & $1.48(0.09)$ & $1.51(0.08)$ & $1.22-1.75$ & $1.22-1.75$ & $1.24-1.75$ \\
\hline BMI $\left(\mathrm{kg} / \mathrm{m}^{2}\right)$ & $20.30(4.18)$ & 20.29 (4.19) & $20.31(4.18)$ & $11.65-36.11$ & $13.78-36.11$ & $11.65-31.75$ \\
\hline $\begin{array}{l}\text { Body Size } \\
\text { Estimation }\left(\mathrm{kg} / \mathrm{m}^{2}\right)\end{array}$ & $-0.68(2.46)$ & & $-0.67(2.46)$ & $-8.50-15.65$ & $-8.50-15.65$ & $-8.45-6.30$ \\
\hline $\begin{array}{l}\text { Body Image } \\
\text { Dissatisfaction }\left(\mathrm{kg} / \mathrm{m}^{2}\right)\end{array}$ & $-1.64(3.69)$ & $-0.69(2.46)$ & $-2.48(3.83)$ & $-13.60-8.50$ & $-8.50-8.50$ & $-13.60-6.80$ \\
\hline
\end{tabular}

Three expert researchers in psychological evaluation, two researchers with substantial experience in studies on body image, two Portuguese elementary school teachers, and one primary education school 
coordinator also participated in the study. They contributed to adaptation of the items to be understandable by the target population of the study.

\section{Measures}

Sociocultural Attitudes towards Appearance Questionnaire (SATAQ-3). The SATAQ-3 assesses the cognitive dimension of body image as beliefs and thoughts about the body and the influence of socio-cultural aspects, particularly the media, on body image. The SATAQ- 3 is composed of 30 items, with Likert-scale answers that range from 1 (definitely disagree) to 5 (definitely agree). The final score is obtained by adding the points for each answer. The original item structure is composed of four dimensions: "General Internalization" (which assesses the overall influence of socially established standards; items 3, 4, 7, 8, 11, 12, 15, 16, and 27; Cronbach's $a=0.96$ ), "Athletic Internalization" (which assesses the influence of athletic models and is related to sports; items 19, 20,23, 24, and 30; Cronbach's $a=$ 0.95 ), "Pressure" (which assesses feelings that are elicited by these standards of body image; items $2,6,10,14$, 18, 22, and 26; Cronbach's a $=0.92$ ), and "Information" (which assesses the media as a source of information on appearance; items 1, 5, 9, 13, 17, 21, 25, 28, and 29; Cronbach's $a=0.96$; Thompson et al., 2004).

Brazilian Figure Rating Scale for children. The Brazilian Figure Rating Scale (FRS) for children was constructed and validated for Brazilian children, 7-12 years of age, by Kakeshita (2008). It consists of 11 silhouettes of each sex that are presented on individual cards, with progressive variations in a range of measures, from leaner $\left(\mathrm{BMI}=12 \mathrm{~kg} / \mathrm{m}^{2}\right)$ to heavier $\left(\mathrm{BMI}=29 \mathrm{~kg} / \mathrm{m}^{2}\right)$. To assess perceptual body image, the participant has to choose the silhouette that most closely matches the image he/she has of his/her body at the time ("Current" $\mathrm{BMI})$. The value of the estimation of body image is obtained by calculating "Current" BMI - "Real" BMI (obtained from measures of weight and height measured during the data collection). Values that are close to zero indicate an accurate perception. Negative values indicate the underestimation of body size. Positive values indicate the overestimation of body size. The participant then must indicate the silhouette that he/ she would like to have ("Desire" BMI). The overall rate of dissatisfaction is obtained by calculating "Desire" BMI "Current" BMI. Values near zero indicate satisfaction. Positive or negative values indicate degrees of dissatisfaction and the desire to have larger or smaller silhouettes, respectively.

\section{Procedure}

The researchers requested permission from the original authors to adapt the SATAQ-3 and from the Brazilian researcher who conducted the study of the cross-cultural adaptation of the SATAQ- 3 to use this scale. Ethical approval was obtained from the Ethics Committee of the University of São Paulo (protocol no. 35025514.7.0000.5407).

The suggestions from the expert researchers, teachers and coordinator were compiled into a single version. We also invited the author who had translated the SATAQ-3 into Brazilian Portuguese. We sent this author the SATAQ-3 version with the appropriate changes and requested suggestions and opinions regarding the changes that were made, according the Beaton, Bombardier, Guillemin and Ferraz (2002) recommendations for cross-cultural adaptation of instruments.

The data collection was performed at the beginning of the school year (March to May). The SATAQ-3 was applied in the classroom by two researchers who were trained to assist and supervise adolescents. Participants took, in general, 10 minutes to respond to the scale. Upon completion of the SATAQ-3, anthropometric measurements were collected. Body Mass Index was classified according to World Health Organization Child Growth Standards: severe thinness (<-3 SD), thinness $(<-2 S D)$, overweight $(>+1 S D)$, obese $(>+2 S D$; World Health Organization, 2007).

\section{Analyses}

A structural equation model or CFA was used to determine the SATAQ-3 factorial validity to test whether the original model proposed by Thompson et al. (2004) provided a good fit to the data. We used six adjustment indices to determine how well the original models fit the data: $\chi^{2}$, goodness-of-fit index (GFI), normed fit index (NFI), comparative fit index (CFI), Tucker-Lewis index (TLI), and root mean square error of approximation (RMSEA).

The RMSEA index estimates how well the model parameters reproduce the population covariance. If the estimated model reproduces exactly the population covariances, then RMSEA equals 0. According to Brown (2006), values $\leq 0.06$ indicate a reasonable fit of the model. The GFI index measures the relative amount of variance and covariance is estimated jointly explained by the matrix. The values range from 0 to 1 and values close to 1 indicate a well-adjusted model. The analyses were performed using SPSS 20.0 software AMOS.

In case of poor adjustment indices relative to the original or Brazilian models of the SATAQ-3, we performed 
EFA using the principal component analysis extraction method. To analyze the rotation matrix, Varimax rotation was used, which is an orthogonal rotation method that minimizes the number of variables with high loads on each factor, thus simplifying interpretation of the factors. This analysis allows representing a number of unique variables using a reduced number of unobserved variables through the existence of a dependency structure between them. As the factor selection criterion, we adopted an eigenvalue $>1$, and loads that were $>0.4$ were considered significant (Hair, Anderson, Tatham, \& Black, 2005). These data were analyzed using SPSS 20 software.

Internal consistency was assessed by calculating Cronbach's a coefficient. Values $\geq 0.70$ were accepted (Hair et al., 2005). Evidence of concurrent validity was verified by the existence of consistent and significant correlations between SATAQ-3 scores and BMI, body image dissatisfaction, and body image accuracy estimation. To obtain evidence of criterion validity, we compared BAS scores between groups with different nutritional status using one-way analysis of variance (ANOVA). These data were analyzed using SPSS 17.0 software. We adopted an alpha value of 0.05 .

\section{Results}

\section{Item Adaptation for the Target Population}

Most of the SATAQ-3 items ( 20 items) did not change from the version that was obtained from the cross-cultural adaptation by Amaral et al. (2011). We made changes to the instrument to make the items more understandable by the target population by specifying some words and expressions in a concrete sense.

For the expression "sources of information," the initial modification was "inform well," but this also would have led to a change of meaning. The item is intended to assess whether the person uses these sources when he wants to be informed about fashion, whereas the expression "inform well" connotes information quality. Thus, the expression "important to know information" was suggested which was subsequently accepted because it retained the original meaning of "sources of information" qualifying the factor of media (advertisements, movies, etc.). Thus, this change was made in items 1, 5, 9, 13, 17, 21, 28, and 29.

Another change that was suggested by the experts was to remove the negative statements that were present in items 3, 6, 12, 13, 19, 27, and 28 . The Brazilian researcher who conducted the SATAQ-3 cross-cultural adaptation also agreed that the inclusion of negative statements may impede understanding, but she highlighted the importance of this type of item, suggesting that negatives (e.g., "no") should be underscored in items that used a reverse score as she did in her investigation with older adolescents (Amaral et al., 2015).

With regard to answer options, the experts considered that the concept of "strongly disagree to strongly agree" was difficult to understand. The suggestions of the adolescents who were interviewed also corroborated the stance of the experts to change it. The option "Strongly disagree" was replaced with "Do not agree at all". "Disagree largely" was changed to "Agree only a little." "Neither agree nor disagree" was changed to "Agree more or less." "Agree largely" was changed to "Agree a little more." "Totally agree" was changed to "Very much agree". We included a non-verbal scale combined with the answer options to introduce more interactive and concrete options.

\section{Psychometric Property Evaluation}

We investigated the data adjustment to the original model (Thompson et al., 2004) using four factors (model 1), although this structure was not verified in the Brazilian version of the SATAQ-3 for adults (Amaral et al., 2013). We also investigated the data adjustment to the model using five factors (model 2), which was obtained by these Brazilian researchers among adults.

The original model of the SATAQ-3 had poor adjustments. The $\mathrm{NFI}, \mathrm{CFI}$, and $\mathrm{TLI}$ were $<0.90$, whereas the $\chi^{2}$ value was high. The factor loadings of items 3 and 6 after the model fit were only 0.071 and 0.140 respectively, so we deleted them to form a new model. However, this adjustment still did not indicate a good fit of the model. The attempted adjustment using model 2 with five factors was even more unsatisfactory. The $\chi^{2}$ was even higher and the RMSEA was $>0.060$. The adjustment indices of these models are shown in Table 2.

None of the models resulted in a good fit of the data. Therefore, we performed EFA. Bartlett's sphericity test was significant $(p<0.001)$. The Kaiser-Meyer-Olkin measure of sample adequacy $(\mathrm{KMO}=0.89)$ indicated that the items adequate for factor analysis. The results presented a factor structure with six factors that explained $50.02 \%$ of the variance. The factor loadings for each variable are presented in Table 3. 
Brazilian version of the sociocultural attitudes towards appearance questionnaire (sataq-3) for adolescents

Table 2. Adjustment Indices of Model 1 (Four Factors) and Model 2 (Five Factors) of the Sociocultural Attitudes towards Appearance Questionnaire (Sataq-3)

\begin{tabular}{cccc}
\hline Indices & $\begin{array}{c}\text { Model 1 } \\
\text { Re-specified } \\
\text { (covariance between errors) }\end{array}$ & $\begin{array}{c}\text { Model 1 } \\
\text { Re-specified } \\
\text { (elimination of Q3 and Q6 + } \\
\text { covariance between errors) }\end{array}$ & $\begin{array}{c}\text { Model 2 } \\
\text { Re-specified } \\
\text { (covariance between errors) }\end{array}$ \\
\hline GFI & $861.25(382)$ & $754.01(330)$ & $952.07(382)$ \\
NFI & 0.859 & 0.869 & 0.856 \\
CFI & 0.817 & 0.834 & 0.798 \\
TLI & 0.888 & 0.898 & 0.867 \\
RMSEA & 0.872 & 0.883 & 0.848 \\
\hline
\end{tabular}

Note. Q3: question 3; Q6: question 6; X2 = chi-squared; DF: degrees of freedom; GFI: Goodness-of-fit Index; NFI: Normed Fit Index; CFI: Comparative Fit Index; TLI: Tucker-Lewis Index; RMSEA: Root Mean Square Error of Approximation.

Table 3. Factor Loads with Varimax Rotation for a 6-Factor Solution and Variance Explained by Each Factor

\begin{tabular}{|c|c|c|c|c|c|c|}
\hline Item & Factor 1 & Factor 2 & Factor 3 & Factor 4 & Factor 5 & Factor 6 \\
\hline 1 & 0.720 & 0.120 & 0.112 & 0.080 & 0.066 & -0.064 \\
\hline 5. & 0.720 & 0.178 & 0.123 & -0.019 & 0.052 & 0.111 \\
\hline 9 & 0.654 & 0.115 & 0.098 & 0.157 & 0.111 & 0.224 \\
\hline 17 & 0.737 & 0.176 & 0.053 & 0.132 & -0.015 & 0.071 \\
\hline 21 & 0.753 & 0.173 & 0.161 & 0.171 & -0.034 & 0.082 \\
\hline 25 & 0.542 & 0.310 & 0.107 & 0.194 & -0.040 & 0.283 \\
\hline 29 & 0.770 & 0.126 & 0.051 & 0.213 & 0.121 & 0.150 \\
\hline 2 & 0.229 & 0.762 & 0.022 & 0.049 & 0.059 & -0.018 \\
\hline 10. & 0.142 & 0.648 & 0.116 & 0.149 & 0.060 & 0.174 \\
\hline 14 & 0.295 & 0.620 & 0.199 & 0.295 & 0.085 & 0.211 \\
\hline 18 & 0.094 & 0.744 & 0.139 & 0.204 & 0.029 & 0.063 \\
\hline 26 & 0.272 & 0.663 & 0.169 & 0.176 & 0.021 & 0.123 \\
\hline 22 & 0.171 & 0.441 & 0.561 & -0.041 & -0.044 & 0.139 \\
\hline 23 & 0.193 & 0.138 & 0.864 & 0.132 & 0.039 & 0.017 \\
\hline 24 & 0.147 & 0.139 & 0.625 & 0.436 & -0.003 & 0.153 \\
\hline 30 & 0.139 & 0.133 & 0.893 & 0.153 & 0.101 & 0.082 \\
\hline 4 & 0.332 & 0.186 & 0.036 & 0.522 & 0.090 & 0.059 \\
\hline 8 & 0.183 & 0.260 & 0.060 & 0.656 & 0.100 & 0.080 \\
\hline 16 & 0.114 & 0.132 & 0.155 & 0.641 & 0.023 & 0.171 \\
\hline 20 & 0.150 & 0.164 & 0.310 & 0.537 & -0.007 & 0.318 \\
\hline 3 & 0.035 & 0.008 & -0.068 & 0.323 & 0.653 & -0.302 \\
\hline 6 & -0.065 & 0.233 & 0.080 & -0.125 & 0.496 & -0.344 \\
\hline 12 & -0.086 & 0.097 & -0.016 & 0.288 & 0.557 & 0.189 \\
\hline 13 & 0.223 & -0.047 & 0.012 & -0.084 & 0.558 & 0.074 \\
\hline 19 & -0.101 & 0.021 & 0.422 & -0.290 & 0.487 & 0.291 \\
\hline 27 & -0.043 & 0.038 & 0.215 & 0.148 & 0.632 & 0.265 \\
\hline 28 & 0.402 & 0.023 & -0.112 & -0.061 & 0.553 & 0.049 \\
\hline 7 & 0.344 & 0.248 & 0.102 & 0.199 & 0.212 & 0.538 \\
\hline 11 & 0.230 & 0.264 & 0.182 & 0.250 & 0.099 & 0.654 \\
\hline 15 & 0.335 & 0.229 & 0.171 & 0.280 & 0.106 & 0.548 \\
\hline Eigenvalue & 8.84 & 2.36 & 2.15 & 1.61 & 1.43 & 1.03 \\
\hline$\%$ variance explained & 29.47 & 7.85 & 7.15 & 5.36 & 4.76 & 3.43 \\
\hline
\end{tabular}


Factor 1 consisted of seven items, including seven of the nine items of the original "Information" subscale. Factor 2 included five of the seven items of the original "Pressure" subscale. Factor 3 included three of the five items of the original "Athletic Internalization" subscale. The original "General Internalization" subscale was subdivided into two factors: factor 4 (four items; social comparison) and factor 6 (three items; desire to look like the ideal body standard). Factor 5 included all eight items with a negative meaning.

With regard to evidence of concurrent validity, correlations between SATAQ-3 scores/subscales, BMI, estimation, and dissatisfaction/satisfaction are presented in Table 4.

Table 4. Values Referring to Concurrent Validity and Internal Consistency Of SATAQ-3

\begin{tabular}{|c|c|c|c|c|c|c|c|}
\hline \multirow{2}{*}{ Scale/Factor } & \multirow{2}{*}{ Variables } & \multicolumn{6}{|c|}{ Sample } \\
\hline & & Total & $\mathbf{p}$ & Boys & $\mathbf{p}$ & Girls & $\mathbf{p}$ \\
\hline \multirow[t]{4}{*}{ SATAQ-3 } & $\mathrm{BMI}$ & -0.038 & 0.483 & $-0.195^{*}$ & 0.011 & 0.094 & 0.219 \\
\hline & Estimation & $0.137^{*}$ & 0.011 & 0.177 & 0.220 & 0.104 & 0.174 \\
\hline & Dissatisfaction & $-0.129^{*}$ & 0.017 & 0.040 & 0.610 & $-0.223^{*}$ & 0.003 \\
\hline & Cronbach's alpha & \multicolumn{2}{|c|}{0.903} & \multicolumn{2}{|c|}{0.886} & \multicolumn{2}{|c|}{0.917} \\
\hline Factor 1 & $\mathrm{BMI}$ & -0.104 & 0.054 & $-0.171^{*}$ & 0.027 & -0.055 & 0.472 \\
\hline \multirow[t]{3}{*}{ "Information" } & Estimation & $0.125^{*}$ & 0.021 & $0.164^{*}$ & 0.034 & 0.096 & 0.208 \\
\hline & Dissatisfaction & -0.060 & 0.269 & 0.074 & 0.341 & -0.093 & 0.222 \\
\hline & Cronbach's alpha & \multicolumn{2}{|c|}{0.877} & \multicolumn{2}{|c|}{0.833} & \multicolumn{2}{|c|}{0.903} \\
\hline Factor 2 & $\mathrm{BMI}$ & 0.097 & 0.073 & -0.120 & 0.123 & $0.255^{*}$ & 0.000 \\
\hline \multirow[t]{3}{*}{ "Pressure" } & Estimation & 0.032 & 0.559 & 0.144 & 0.062 & -0.059 & 0.439 \\
\hline & Dissatisfaction & $-0.192^{*}$ & 0.000 & 0.026 & 0.743 & $-0.314^{*}$ & 0.000 \\
\hline & Cronbach's alpha & \multicolumn{2}{|c|}{0.829} & \multicolumn{2}{|c|}{0.757} & \multicolumn{2}{|c|}{0.877} \\
\hline Factor 3 & $\mathrm{BMI}$ & -0.030 & 0.578 & -0.080 & 0.304 & 0.020 & 0.798 \\
\hline "Athletic & Estimation & 0.100 & 0.066 & $0.176^{*}$ & 0.023 & 0.029 & 0.705 \\
\hline \multirow[t]{2}{*}{ Internalization" } & Dissatisfaction & 0.028 & 0.612 & -0.012 & 0.874 & -0.033 & 0.665 \\
\hline & Cronbach's alpha & \multicolumn{2}{|c|}{0.840} & \multicolumn{2}{|c|}{0.836} & \multicolumn{2}{|c|}{0.842} \\
\hline Factor 4 & $\mathrm{BMI}$ & -0.080 & 0.141 & $-0.180^{*}$ & 0.019 & -0.008 & 0.914 \\
\hline "General & Estimation & $0.139^{*}$ & 0.010 & $0.156^{*}$ & 0.044 & 0.131 & 0.087 \\
\hline \multirow[t]{2}{*}{ Internalization" } & Dissatisfaction & -0.041 & 0.451 & 0.073 & 0.346 & -0.061 & 0.427 \\
\hline & Cronbach's alpha & \multicolumn{2}{|c|}{0.706} & \multicolumn{2}{|c|}{0.609} & \multicolumn{2}{|c|}{0.751} \\
\hline Factor 5 & $\mathrm{BMI}$ & -0.018 & 0.738 & -0.151 & 0.054 & 0.110 & 0.151 \\
\hline \multirow[t]{3}{*}{ "Reverse" } & Estimation & 0.075 & 0.165 & 0.001 & 0.995 & 0.147 & 0.053 \\
\hline & Dissatisfaction & $-0.114^{*}$ & 0.036 & 0.025 & 0.746 & $-0.213^{*}$ & 0.005 \\
\hline & Cronbach's alpha & \multicolumn{2}{|c|}{0.667} & \multicolumn{2}{|c|}{0.651} & \multicolumn{2}{|c|}{0.686} \\
\hline Factor 6 & $\mathrm{BMI}$ & -0.028 & 0.611 & -0.108 & 0.162 & 0.051 & 0.505 \\
\hline "General & Estimation & $0.132^{*}$ & 0.015 & 0.138 & 0.074 & 0.126 & 0.097 \\
\hline \multirow[t]{2}{*}{ Internalization" } & Dissatisfaction & $-0.162^{*}$ & 0.003 & -0.028 & 0.718 & $-0.227^{*}$ & 0.003 \\
\hline & Cronbach's alpha & \multicolumn{2}{|c|}{0.773} & \multicolumn{2}{|c|}{0.786} & & \\
\hline
\end{tabular}

The internal consistency was adequate for the total sample for both boys and girls. Cronbach's a indicated appropriate internal consistency for all factors (>0.76), with the exception of factor 4 ("General Internalization") and factor 5 ("Reverse Scores"), which showed acceptable values (>0.65). Cronbach's a for internal consistency of the SATAQ-3 and its six factors for the overall sample, stratified by sex, are presented in Table 4.

For analyses of criterion validity, ANOVA was performed after excluding participants whose nutritional status was classified as extreme underweight $(n=1)$ and underweight $(n=3)$. The one-way ANOVA revealed 
no significant effects of nutritional status on SATAQ-3 scores $\left(F^{2,340}=0.40, p>0.05\right)$. We chose not to perform ANOVAs of factors because of the small number of observations for some factors in each group.

\section{Discussion}

The present study produced another Brazilian version of the SATAQ-3 for adolescents, 10 to 13 years of age. The factor structure presented six factors that reflected dimensions that were similar to the original study: "Information Sources" (factor 1), "Pressure" (factor 2), "Athletic Internalization" (Factor 3), "General Internalization" (by social comparison; factor 4), "Reverse Scores" (factor 5), and "General Internalization" (wanting body ideals; factor 6). The main difference from the original factor structure of the SATAQ-3 refers to the appearance of the factor that grouped the reverse score items (Thompson et al., 2004). These data also reflect the difficulty in understanding the negative items by some of the respondents, both adults and adolescents. Nonetheless, they considered the importance of retaining these items for measuring the construct (Amaral et al., 2011; Markland \& Oliver, 2008; Wheeler, Vassar, \& Hale, 2011).

Other studies showed that the original factor structure of the SATAQ-3 had not been verified with different versions and samples. Items from the original factors were grouped on different factors that do not reflect any of the original dimensions (Jackson \& Chen, 2010; Sánchez-Carracedo et al., 2012; Swami, 2009). These findings indicate that the items can be interpreted differently in other cultures and populations when versions of the same instrument are applied.

The main difference between our version and the Brazilian validation among adult samples (Amaral et al., 2013) is the emergence of a sixth factor that is a subscale of the "General Internalization" dimension: General Internalization (by social comparison) and General Internalization (wanting body ideals). Similar changes were observed in the SATAQ-3 factor structure among adolescents who were $>13$ years old, in which Amaral et al. (2015) obtained a structure with seven factors, and the "General Internalization" and "Information" dimensions were subdivided into four factors.

The correlations between SATAQ-3 scores and FRS indices, in addition to BMI, suggest evidence of concurrent validity of the instrument, demonstrating the associations with these variables, especially body dissatisfaction among girls. This finding corroborates the literature since girls are more dissatisfied than boys (De Carli, Abdalla, Machado, \& Borges, 2017) and considering that the dissatisfaction is moderated by the social comparison and the internalization (Holland \& Tiggemann, 2016). The association between SATAQ-3 scores and body image dissatisfaction was also found in the Brazilian cross-cultural adaptation study with adult samples (Amaral et al., 2013) and later with adolescents who were $>13$ years of age (Amaral et al., 2015). This association was also found in the SATAQ-3 development study (Thompson et al., 2004).

With regard to the instrument factors that were obtained in the present study, we found that only the "Pressure" (factor 2) and "General Internalization" (factor 6) dimensions were associated with dissatisfaction. This corroborates the findings of other studies that considered that these dimensions were stronger predictors of dissatisfaction compared with the other dimensions, such as "Athletic Internalization" and "Information" (Cafri, Yamamiya, Brannick, \& Thompson, 2005; Knauss et al., 2009; Stefanile et al., 2011).

With regard to the instrument's reliability, the internal consistency was suitable for the overall sample and for groups stratified by sex, with values $>0.88$. However, the analysis of this parameter for each of the six dimensions revealed that two factors (factors 4 and 6 ) had values between 0.70 and 0.80 , and factor 5 had values between 0.60 and 0.70 . Cronbach's a for factor 5 was considered acceptable. This factor, which consisted of negative items, has been shown to have poor internal consistency in both Brazilian studies (Amaral et al., 2015; Amaral et al., 2011) and with international samples (Markland \& Oliver, 2008; Wheeler et al., 2011), which led these authors to conclude that these items are problematic.

We assessed socio-cultural pressure using the SATAQ-3 in 10- to 13-year-old Brazilian adolescents. Media internalization is an important risk factor for eating disorders among adolescents. It is worth noting that other instruments that evaluate SATAQ-3 constructs, such as the Three Factors Influence Scale (EITF), which measures the influence of parents, friends and the media on body dissatisfaction and eating disorders, was not used in Brazilian samples at the age of the present study. Despite evaluating the cognitive dimension of the body image, this instrument does not evaluate the internalization of the media, a consistently aspect pointed by researchers as a mediator of dissatisfaction and risk eating behaviors (Holland \& Tiggemann, 2016). 
Our results will allow researchers to further evaluate this variable using the version of the SATAQ-3 that was developed in the present study. This is important when considering that media literacy has become a central target of many prevention programs. Media internalization should be one of the primary outcomes that is measured in this type of study (Wilksch \& Wade, 2012). Thus, Brazilian researchers can assess media internalization in this age group by conducting both correlational and interventional studies.

Also, future researchers should adapt and test among Brazilian samples the fourth version of the SATAQ developed by Schaefer et al. (2015). This new version updated the SATAQ-3 to enable a more comprehensive assessment of the "Pressure" dimension, including items that assess pressures that are related to family, peers, and the media, in addition to developing specific items for the internalization of male and female appearance ideals. The development and validation study revealed evidence of validity and reliability of the SATAQ-4 in American, Italian, Australian, and English women and provided preliminary data for men. This version was not published when the present study began. As of early 2017, no Brazilian version of the SATAQ-4 has been published.

Some limitations of the present study should be highlighted. First, we used an instrument that assesses general dissatisfaction with body image (the FRS) as a measure of concurrent validity. Second, few associations between SATAQ-3 scores and other variables were evaluated, such as the influence of peers and family, physical investment, and other media exposure measures. Third, we did not include a comparison group, such as clinical groups with diagnoses of eating disorders or who are at risk of developing these disorders. Future research should evaluate these variables to obtain other psychometric measures that can be used to determine the discriminant validity of the instrument.

Importantly, we did not use other instruments that assess similar constructs as the SATAQ-3 to study convergent validity because few scales have been cross-culturally adapted and validated for this age group. For example, the Tripartite Influence Scale measures the influence of parents, friends, and media on body dissatisfaction and eating disorders. A cross-cultural adaptation has been properly performed for Brazilian Portuguese, but its psychometric properties were evaluated only among undergraduate students. This highlights the need to further validate the TIS for adolescent samples.

\section{Conclusions}

The version of the SATAQ-3 that was developed herein is suitable for administration in the Brazilian adolescent population to analyze sociocultural pressures and the internalization of appearance ideals. The factor structure presented six factors that reflected dimensions that were similar to the original study. The main difference from the original factor structure of the SATAQ-3 refers to the appearance of a factor that grouped the reverse score items. We also demonstrated concurrent validity of the SATAQ-3 because its scores were correlated with BMI and body image dissatisfaction. The SATAQ-3 had satisfactory internal consistency among our 10- to 13-year-old Brazilian adolescent sample of both sexes.

\section{References}

Amaral, A. C. S., Conti, M. A., Ferreira, M. E. C., \& Meireles, J. F. F. (2015). Avaliação Psicométrica do Questionário de Atitudes Socioculturais em Relação à Aparência-3 (SATAQ-3) para adolescentes. Psicologia: Teoria e Pesquisa, 31(4), 471-479. doi: 10.15900102-37722015042419471479

Amaral, A. C. S., Cordás, T. A., Conti, M. A., \& Ferreira, M. E. C. (2011). Equivalência semântica e avaliação da consistência interna da versão em português do Sociocultural Attitudes Towards Appearance Questionnaire-3 (SATAQ-3). Cadernos de Saúde Pública, 27(8), 1487-1497. doi: 10.1590/S0102311X2011000800004

Amaral, A. C. S., Ribeiro, M. S., Conti, M. A., Ferreira, C. S., \& Ferreira, M. E. C. (2013). Psychometric evaluation of the Sociocultural Attitudes Towards Appearance Questionnaire-3 among Brazilian young adults. The Spanish Journal of Psychology, 16(e94), 1-10. doi:10.1017/sjp.2013.94

Beaton, D. E., Bombardier, C., Guillemin, F., \& Ferraz, M. B. (2002). Recommendations for the cross-cultural adaptation of healthy status measures. Chigaco, IL: American Academy of Orthopaedic Surgeons Institute for Work \& Health.

Brown, T. A. (2006). Confirmatory factor analysis for applied research. New York: The Guilford Press.

Cafri, G., Yamamyia, Y., Brannick, M., \& Thompson, J. K. (2005). The influence of sociocultural factors on body image: A meta-analysis. Clinical Psychology: Science and Practice, 12, 421-433. doi: 10.1093/clipsy.bpi053

Calogero, R. M., Davis, W. N., \& Thompson, J. K. (2004). The Sociocultural Attitudes Towards Appearance Questionnaire (SATAQ-3): Reliability and normative comparisons of eating disordered patients. Body Image, 1(2), 193-198. doi: 10.1016/j.bodyim.2004.01.004

De Carli, P. B., Abdalla, P. P., Machado, D. R. L., \& Borges, G. A. (2017). Insatisfação com a imagem corporal de meninas de 11 a 14 anos de idade. Caderno de Educação Física e Esporte, 14(1), 1-10. Retrieved from http://e-revista.unioeste.br/index.php/cadernoedfisica/article/ view/14975/pdf_1

Fidelix, Y. C., Minatto, G., Ribeiro, R. R., Santos, K. D., \& Petroski, E. L. (2013). Dados sociodemográficos, estado nutricional e maturação sexual de escolares do sexo masculino: exposição à insatisfação com a imagem corporal. Revista de Educação Física/UEM, 24(1), 83-92. doi: 10.4025/reveducfis.v24.1.17353 
Brazilian version of the sociocultural attitudes towards appearance questionnaire (sataq-3) for adolescents

Fortes, L., S., Amaral, A. C. S., Almeida, S. S., \& Ferreira, M. E. C. (2013). Internalização do ideal de magreza e insatisfação com a imagem corporal em meninas adolescentes. PSICO, Porto Alegre, PUCRS, 44(3), 432-438. Retrieved from http://revistaseletronicas.pucrs.br/ revistapsico/ojs/index.php/revistapsico/article/view/12301

Fortes, L., S., Meireles, J. F. F., Paes, S. T., Dias, F. C., Cipriani, F. M., \& Ferreira, M.E. C. (2015). Associação da internalização dos padrões corporais, sintomas depressivos e comportamento alimentar restritivo em jovens do sexo masculino. Ciência \& Saúde Coletiva, 20(11), 3457-3466. doi: 10.1590/1413-812320152011.00152015

Hair, J. F., Anderson, R. E., Tatham, R. L., \& Black, W. C. (2005). Análise multivariada de dados. [Multivariate data analysis]. Porto Alegre, Brazil: Bookman.

Hargreaves, D. A., \& Tiggemann, M. (2004). Idealized media images and adolescent body image: "Comparing" boys and girls. Body Image, 1(4), 351-361. doi: 10.1016/j.bodyim.2004.10.002

Heinberg, L. J., Coughlin, J.W., Pinto, A. M., Haug, N., Brode, C., \& Guarda, A. S. (2008). Validation and predictive utility of the Sociocultural Attitudes Toward Appearance Questionnaire for Eating Disorders (SATAQ-ED): Internalization of sociocultural ideals predicts weight gain. Body Image, 5, 279-290. doi: 10.1016/ j.bodyim.2008.02.001

Heinberg, L. J., Thompson, J. K., \& Stormer, S. (1995). Development and validation of the sociocultural attitudes towards Appearance Questionnaire. International Journal of Eating Disorders, 17(1), 81-89. doi: 10.1002/1098-108X(199501)17:1<81::AIDEAT2260170111>3.0.CO;2-Y

Holland, G., \& Tiggemann, M. (2016). A systematic review of the impact of the use of social networking sites on body image and disordered eating outcomes. Body image, 17, 100-110. doi: 10.1016/j.bodyim.2016.02.008

Jackson, T., \& Chen, H. (2010). Factor structure of the Sociocultural Attitudes Towards Appearance Questionnaire-3 (SATAQ-3) among adolescent boys in China. Body Image, 7, 349-355. doi: 10.1016/j. bodyim.2010.07.003

Kakeshita, I. S. (2008). Adaptation and validation of a Figure Rating Scales for Brazilian children and adults (Doctoral thesis, Faculdade de Filosofia, Ciências e Letras de Ribeirão Preto, Universidade de São Paulo, Ribeirão Preto). doi: 10.11606/T.59.2008.tde-25052008-170240

Karazsia, B. T., \& Crowther, J. H. (2008). Psychological and behavioral correlates of the SATAQ-3 with males. Body Image, 5, 109-115. doi: 10.1016/j.bodyim. 2007.08.004

Knauss, C., Paxton, S. J., \& Alsaker, F. D. (2009). Validation of the German version of the Sociocultural Attitudes Towards Appearance Questionnaire (SATAQ-G). Body Image, 6, 113-120. doi: 10.1016/j. bodyim.2009.01.002

Laus, M. F., Kakeshita, I. S., Costa, T. M. B., Ferreira, M. E. C., Fortes, L. D. S., \& Almeida, S. S. (2014). Body image in Brazil: Recent advances in the state of knowledge and methodological issues. Revista de Saúde Pública, 48(2), 331-346. doi: 10.1590/S0034-8910.2014048004950

Madanat, H. N., Hawks, S. R., \& Brown, R. B. (2006). Validation of the Sociocultural Attitudes Towards Appearance Questionnaire-3 among a random sample of Jordanian women. Body Image, 3, 421-425. doi: 10.1016/j.bodyim.2006.09.004

Markland, D., \& Oliver, E. J. (2008). The Sociocultural Attitudes Questionnaire-3: A confirmatory factor analysis. Body Image, 5, 116-121. doi: 10.1016/j. bodyim.2007.10.001

Montoya, Y. L., Quenaya, A., \& Mayta-Tristán, P. (2015). Mass media influence and risk of developing eating disorders in female students from Lima, Peru. Archivos Argentinos de Pediatria, 113(6), 519-525. doi: 10.5546/aap.2015.eng.519

Pasquali, L. (2010). Instrumentação Psicológica: fundamentos e Práticas. Porto Alegre: Artmed.

Ricciardelli, L. A., \& McCabe, M. P. (2004). A biopsychosocial model of disordered eating and the pursuit of muscularity in adolescent boys. Psychological Bulletin, 130, 179-205. doi:10. 1037/0033-2909.130.2.179

Rodgers, R., Cabrol, H., \& Paxton, S. J. (2011). An exploration of the tripartite influence model of body dissatisfaction and disordered eating among Australian and French college women. Body image, 8(1), 208-215. doi: 10.1016/j.bodyim.2011.04.009

Rohde, P., Stice, E., \& Marti, C. N. (2015). Development and predictive effects of eating disorder risk factors during adolescence: Implications for prevention efforts. International Journal of Eating Disorders, 48(2), 187-198. doi: 10.1002/eat.22270

Rousseau, A., Valls, M., \& Chabrol, H. (2010). The Sociocultural Attitudes Towards Appearance Scale-3(SATAQ-3): Etude de validation de la version française. L'Encéphale, 36, 270-276. doi:10.1016/j.encep.2008.03.013

Sánchez-Carracedo, D., Barrada, J. R., López-Guimerà, G., Fauquet, J., Almenara, C. A., \& Trepat, E. (2012). Analysis of the factor structure of the Sociocultural Attitudes Towards Appearance Questionnaire (SATAQ-3) in Spanish secondary-school students through exploratory structural equation modeling. Body Image, 9(1), 163-171. doi: 10.1016/j.bodyim.2011.10.002

Schaefer, L. M., Burke, N. B., Thompson, J. K., Heinberg, L. J., Calogero, ... Swami, V. (2015). Development and Validation of the Sociocultural Attitudes Towards Appearance Questionnaire-4 (SATAQ-4). Psychological Assessment, 27(1), 54-67. doi: 10.1037/a0037917

Spurr, S., Berry, L., \& Walker, K. (2013). Exploring adolescent views of body image: the influence of media. Issues in Comprehensive Pediatric Nursing, 36(1-2), 17-36. doi: 10.3109/01460862.2013.776145

Stefanile, C., Matera, C., Nerini, A., \& Pisani, E. (2011). Validation of an Italian version of the Sociocultural Attitudes Towards Appearance Questionnaire-3 (SATAQ-3) on adolescent girls. Body Image, 8, 432-436. doi: 10.1016/j.bodyim.2011.06.001

Swami V. (2009). An examination of the factor structure of the Sociocultural Attitudes Towards Appearance Questionnaire-3 in Malaysia. Body Image, 6, 129-132. doi: 10.1016/j.bodyim.2009.01.003

Thompson, J. K., Coovert, M. D., \& Stormer, S. M. (1999). Body image, social comparison, and eating disturbance: A covariance structure modeling investigation. International Journal of Eating Disorders, 26(1), 43-51. doi: 10.1002/ (SICI)1098-108X(199907)26:1\%3C43::AID-EAT6\%3E3.0.CO;2-R

Thompson, J.K., van den Berg, P., Roehrig, M., Guarda, A.S., \& Heinberg, L. J. (2004). The Sociocultural Attitudes Towards Appearance Scale-3 (SATAQ-3): Development and validation. International Journal of Eating Disorders, 35, 293-304. doi: 10.1002/eat.10257

Vries, D. A., Peter, J., Graaf, H., \& Nikken, P. (2016). Adolescents' social network site use, peer appearance-related feedback, and body dissatisfaction: testing a mediation model. Journal of Youth Adolescence, 45, 211-224. doi: 10.1007/s10964-015-0266-4

Watson, R., \& Vaughn, L. M. (2006). Limiting the effects of the media on body image: Does the length of a media literacy intervention make a difference? Eating Disorders, 14, 385-400. doi: 10.1080/10640260600952530

Wertheim, E. H., \& Paxton, S. J. (2011). Body Image development in adolescent girls. In T. F. Cash \& L. Smolak (Eds.), Body image: $A$ 
handbook of science, practice, and prevention. (2nd ed., pp. 76-84). New York: The Guilford Press.

Wheeler, D. L., Vassar, M., \& Hale, W. D. (2011). A gender based measurement invariance study of the Sociocultural Attitudes Towards Appearance Questionnaire-3.Body Image, 8, 168-172. doi: 10.1016/j. bodyim.2010.12.004
Wilksch, S. M., \& Wade, T. D. (2012). Examination of the Sociocultural Attitudes Towards Appearance Questionnaire-3 (SATAQ-3) in a mixedgender young adolescent population. Psychological Assessment, 24, 352-364. doi: $10.1037 / \mathrm{a} 0025618$

World Health Organization. (2007). Growth reference 5-19years. Retrieved from http://www.who.int/growthref/who2007_bmi_for_age/en/

Gabriela Salim Xavier Moreira, Doutora em Psicologia pela Faculdade de Filosofia, Ciências e Letras de Ribeirão Preto pela Universidade de São Paulo-USP, Psicóloga em Clínica Particular. Endereço para correspondência: Avenida dos Bandeirantes, 3900 , FFCLRP, CEP 1040-901. E-mail: gabrielasalimxavier@gmail.com

Luciana Lorenzato, Mestre em Psicobiologia pela Faculdade de Filosofia, Ciências e Letras de Ribeirão Preto pela Universidade de São Paulo-USP, é Nutricionista em Clínica Particular. E-mail: lucianalorenzato@yahoo.com.br

Carmem Beatriz Neulfeld, Doutora em Psicologia pela Pontifícia Universidade Católica do Rio Grande do Sul, Pós-Doutora pela Universidade Federal do Rio de Janeiro, é Professora Associada na Faculdade de Filosofia, Ciências e Letras de Ribeirão Preto da Universidade de São Paulo-USP. E-mail: cbneulfeld@usp.br

Sebastião Sousa Almeida, Doutor em Farmacologia pela Faculdade de Medicina de Ribeirão Preto-USP, Pós-Doutor pela Boston University School of Medicine-USA, é Professor Titular na Faculdade de Filosofia, Ciências e Letras de Ribeirão Preto da Universidade de São Paulo-USP. E-mail: sebasalm@usp.br

Received in 09.ago.17 Revised in 21.fev.19 Accepted in 05.jun.19 